\title{
BMJ Global Health Community engagement for COVID-19 prevention and control: a rapid evidence synthesis
}

\author{
Brynne Gilmore (D) , ${ }^{1}$ Rawlance Ndejjo, ${ }^{2}$ Adalbert Tchetchia, ${ }^{3}$ Vergil de Claro, ${ }^{4}$ \\ Elizabeth Mago, ${ }^{5}$ Alpha A Diallo, ${ }^{6}$ Claudia Lopes, ${ }^{7}$ Sanghita Bhattacharyya ${ }^{8,9}$
}

To cite: Gilmore B,

Ndejjo R, Tchetchia A, et al. Community engagement for COVID-19 prevention and control: a rapid evidence synthesis. BMJ Global Health 2020;5:e003188. doi:10.1136/ bmjgh-2020-003188

Handling editor Seye Abimbola

- Additional material is published online only. To view, please visit the journal online (http://dx.doi.org/10.1136/ bmjgh-2020-003188).

Received 17 June 2020 Revised 24 August 2020 Accepted 25 August 2020
Check for updates

C Author(s) (or their employer(s)) 2020. Re-use permitted under CC BY-NC. No commercial re-use. See rights and permissions. Published by BMJ.

For numbered affiliations see end of article.

Correspondence to Dr Brynne Gilmore; brynne.gilmore@ucd.ie

\section{ABSTRACT}

Introduction Community engagement has been considered a fundamental component of past outbreaks, such as Ebola. However, there is concern over the lack of involvement of communities and 'bottom-up' approaches used within COVID-19 responses thus far. Identifying how community engagement approaches have been used in past epidemics may support more robust implementation within the COVID-19 response.

Methodology A rapid evidence review was conducted to identify how community engagement is used for infectious disease prevention and control during epidemics. Three databases were searched in addition to extensive snowballing for grey literature. Previous epidemics were limited to Ebola, Zika, SARS, Middle East respiratory syndromeand H1N1 since 2000. No restrictions were applied to study design or language.

Results From 1112 references identified, 32 articles met our inclusion criteria, which detail 37 initiatives. Six main community engagement actors were identified: local leaders, community and faith-based organisations, community groups, health facility committees, individuals and key stakeholders. These worked on different functions: designing and planning, community entry and trust building, social and behaviour change communication, risk communication, surveillance and tracing, and logistics and administration.

Conclusion COVID-19's global presence and social transmission pathways require social and community responses. This may be particularly important to reach marginalised populations and to support equity-informed responses. Aligning previous community engagement experience with current COVID-19 community-based strategy recommendations highlights how communities can play important and active roles in prevention and control. Countries worldwide are encouraged to assess existing community engagement structures and use community engagement approaches to support contextually specific, acceptable and appropriate COVID-19 prevention and control measures.

\section{INTRODUCTION}

Community engagement within health is crucial to achieve primary healthcare and promote people-centred services. ${ }^{1-3}$ It can

\section{Key questions}

What is already known?

- Community engagement is considered a fundamental component during outbreaks and is important to ensure contextually appropriate interventions.

What are the new findings?

- How community engagement can be used for COVID-19 has yet to be thoroughly explored. Findings from this rapid review highlight the main community engagement actors and approaches and the interventions that they conduct within prevention and control of infectious disease. This review also notes the lack of documented community engagement activities from high-income countries.

\section{What do the new findings imply?}

- These findings highlight that well-implemented community engagement strategies can be used to support designing of interventions, building trust and community entry, social and behaviour chance communication, risk communication, surveillance and contract tracing, and logistical and administrative support during COVID-19 prevention and control responses.

support buy-in and sustainability of health interventions, ${ }^{4}$ health advocacy, ${ }^{5}$ improved quality and satisfaction of services, ${ }^{6}$ and contribute to health systems responsiveness ${ }^{7}$ and strengthening. ${ }^{8}$ Community engagement refers to involvement and participation of individuals, groups and structures within a parameter of a social boundary or catchment area of a community for decision-making, planning, design, governance and delivery of services. ${ }^{9}$ It is used as a parent notion with terms like communication, social mobilisation, community participation, community action and empowerment ${ }^{10}$ with emphasis on the agency of community members or groups, considering them as active rather than passive participants. ${ }^{11} 12$ Community engagement is seen as critical in many health initiatives, 
such as for communicable disease ${ }^{10}$ and maternal and child health initiatives, ${ }^{13}$ and more recently has been considered a fundamental component during outbreaks, largely arising during the 2014-2015 Ebola epidemic in West Africa.

The way people interact and live with each other through their structures, as well as their historical pathways require considerations on how to effectively adapt and respond to any disease outbreak. For example, differences in political-cultural and social structures, systems and processes among communities and social norms and beliefs affect health behaviours and outcomes during outbreaks. ${ }^{14}$ Experience with public health emergencies of international concern highlight the need for contextually appropriate community engagement strategies. ${ }^{15-21}$ Moreover, a recent rapid review noted key lessons in risk communication for control of outbreaks to include communities taking a central role in the response, involving local leaders and groups, tailoring interventions to communities and ensuring a two-way communication. ${ }^{17}$

Early implementation of prevention and control activities during the 2014-2015 Ebola epidemic had several barriers, including suspicions regarding the existence of the disease and motives of the government and international organisations. ${ }^{15} 19$ To address these barriers, community engagement became a key pillar to the response. Several measures to engage communities were undertaken, including building partnerships with local and religious leaders and working with the community to develop and adjust key messages for behavioural change,${ }^{1522}$ and initiation of coordinated response mechanisms, such as Sierra Leone's Social Mobilisation Action Consortium (SMAC), which supported community engagement activities during the Ebola outbreak from 2014 to $2016 .^{23}$ These measures significantly contributed to the success achieved in controlling the outbreak and ensuring the resilience of the health system. ${ }^{91522}$

In relation to COVID-19, community engagement can be critical for creating local and context-specific solutions to prevention and control responses. ${ }^{24}$ Through this 'bottom-up approach', communities participate in 'decision-making processes of planning, design, governance and delivery of services aimed at improving population health and reducing health inequalities'. The COVID-19 pandemic as a total social phenomenon should include actively engaging and adapting local views, voices and concerns in health crisis response efforts. ${ }^{24}$ Moreover, the WHO's recommended measures to prevent and control COVID-19, such as physicalsocial distancing, case identification and contact tracing require understanding of the different social dynamics in communities and how these can better be leveraged to minimise the impact of the epidemic. ${ }^{25}{ }^{26}$ The measures have a huge reliance on communities reigniting the importance of community engagement to build trust and delay disease spread as drug and vaccine development efforts continue.
However, there is concern over the lack of involvement of communities within COVID-19. Rajan and colleagues note the limited number of WHO member states reporting to have a COVID-19 community engagement plan. ${ }^{27}$ The scientific community-mainly drawn by social scientists-has called for the attention of funders and implementers on the relevance of community engagement for COVID-19, ${ }^{24}{ }^{28-30}$ with other international stakeholders, including WHO, UNICEF and the International Federation of Red Cross and Red Crescent Societies (IFRC) echoing its importance. ${ }^{25}$ This concern must be understood considering that, at the beginning of the pandemic, there was a tendency to prioritise biomedical and epidemiological interventions even if international stakeholders have early and progressively defined some guidelines on risk communication and community engagement.

Recent reviews on global evidence for COVID-19 have focused on community health workers $(\mathrm{CHWs})^{31}$ providing important evidence and insights to guide response. However, there is no evidence synthesis that addresses how community engagement can be used for COVID-19 prevention and control. Thus, we conducted a rapid evidence review on community engagement for infectious disease prevention and control to learn lessons for COVID-19 and future pandemic response.

\section{Review focus}

This review wanted to understand how community engagement is used for infectious disease prevention and control during epidemics'. In doing so, we reviewed evidence from previous epidemics and aimed to identify what approaches and community actors are involved, what interventions are conducted, who the target groups of community engagement are and how equity considerations are incorporated, what the linkages and relationship to other health system stakeholders are, and what the main implementation considerations for successful community engagement for infectious disease prevention and control are. To address these questions, we draw on findings from five previous epidemics: Ebola, SARS, Middle East respiratory syndrome (MERS), Zika and H1N1.

\section{METHODS}

Given the emergency nature of the recent COVID-19 global pandemic, we conducted a rapid evidence review to support timely findings. Rapid reviews are a form of evidence synthesis that tailor the methodology of a systematic review to produce contextually relevant evidence on an arising topic in a timely and efficient manner. ${ }^{32}$ To support the expedited nature of rapid reviews, they can deviate from traditional reviews in several areas, including narrowing the scope, limiting the number of searches or electronic databases, using one reviewer for study screening and selection, and parallelisation of review tasks. ${ }^{32}$ This rapid review followed the methodology 


\begin{tabular}{|c|c|c|}
\hline Topic & Inclusion criteria & Exclusion criteria \\
\hline Intervention/population & $\begin{array}{l}\text { Describes a specific community engagement approach or } \\
\text { activity }\end{array}$ & $\begin{array}{l}\text { Exclusively community health worker } \\
\text { programmes } \\
\text { Structures without community members } \\
\text { serving the same community }\end{array}$ \\
\hline Focus & $\begin{array}{l}\text { Prevention and/or control of infectious diseases: Ebola, } \\
\text { SARS, Middle East respiratory syndrome, Zika and H1N1 }\end{array}$ & $\begin{array}{l}\text { Not focused on prevention and/or control } \\
\text { of infectious disease }\end{array}$ \\
\hline Scope of intervention & $\begin{array}{l}\text { Community level-defined by 'the social boundaries } \\
\text { that define the individuals and households whose health } \\
\text { outcomes matter as a health system goal, and also the } \\
\text { social context for the relationships that underpin the success } \\
\text { of many health systems interventions'. }{ }^{77}\end{array}$ & Not community focused \\
\hline Time & Published on or after 2000 & Published before 2000 \\
\hline Article type & $\begin{array}{l}\text { Primary, empirical studies, of any design, programme } \\
\text { reports and descriptions that provide learning on specific CE } \\
\text { approaches }\end{array}$ & $\begin{array}{l}\text { Commentaries, abstracts; no specific } \\
\text { community engagement approach detailed }\end{array}$ \\
\hline Language & $\begin{array}{l}\text { All languages included, searching done in English and some } \\
\text { French terms }\end{array}$ & No exclusion criteria \\
\hline
\end{tabular}

suggested by the Alliance for Health Policy and Systems Research. ${ }^{33}$ A co-production team comprising all authors of this paper was established through the collaborative platform 'Community Health-Community of Practice', supported by UNICEF.

A protocol was developed and agreed on by the research team, which comprises academics, implementers and policy makers from multiple disciplines and backgrounds. The team then conducted a rapid evidence review of academic and grey literature in May 2020. The main focus of the review was to identify what types of community engagement approaches are used within infectious disease prevention and control, which required articles to describe a minimum of one specific initiative. As such, no criteria for effectiveness or outcomes were applied. Full inclusion and exclusion criteria can be found in table 1 .

In line with community agency and taking into account a framework developed by UNICEF and revised by Community Health-Community of Practice, the definition of community engagement adopted in this study covers the range of collaborative processes with community actors that transcend beyond CHWs and includes community groups, informal providers, faith organisations or social networks. ${ }^{34}$ We excluded CHW approaches and interventions as reviews of this nature have already been conducted, ${ }^{31}$ though we included articles if they described community engagement approaches alongside CHW programmes and narrowed the scope to include five recent infectious disease outbreaks: Ebola, SARS, MERS, Zika and H1N1.

\section{Databases and snowballing}

In line with rapid review recommendations, we limited our searches to three databases: PubMed, CINAHL and Scopus. We conducted an extensive grey literature and snowball search by reviewing websites of numerous public health organisations and repositories, as well as emailing the authors' respective networks. Online supplemental file 1 provides a list of snowballing sources and completed database searches. Search terms were in both French and English. In addition, all included articles' references were checked. To expedite the review process, two authors conducted the database search; three conducted grey literature and snowballing searches; and two conducted reference searching.

\section{Article screening and extraction}

All returned results were entered into Covidence, a systematic review information management system, where duplicates were removed. The remaining articles were screened at title and abstract stage, and full-text stage independently by two reviewers, with a third resolving any discrepancies. Two team members independently screened all returned snowballing resources at full-text stage, with a third reviewer resolving any discrepancies. All authors participated in the screening.

Predefined and piloted data extraction tables were developed. Two authors initially extracted data from the included articles, with other authors reviewing all extractions for reliability and consistency. Content on community engagement actors/approaches and intervention focus was extracted directly as the articles reported if applicable; however, this often did not occur, leaving the review team to extrapolate and categorise. Given that the research question seeks to identify what has been used, no quality ratings were applied to the included articles.

\section{Public and patient involvement (PPI)}

There were no funds or time allocated for PPI, so we were unable to involve patients. We encourage throughout the findings for programme and policy makers to involve communities within the design and implementation of their respective programmes. 


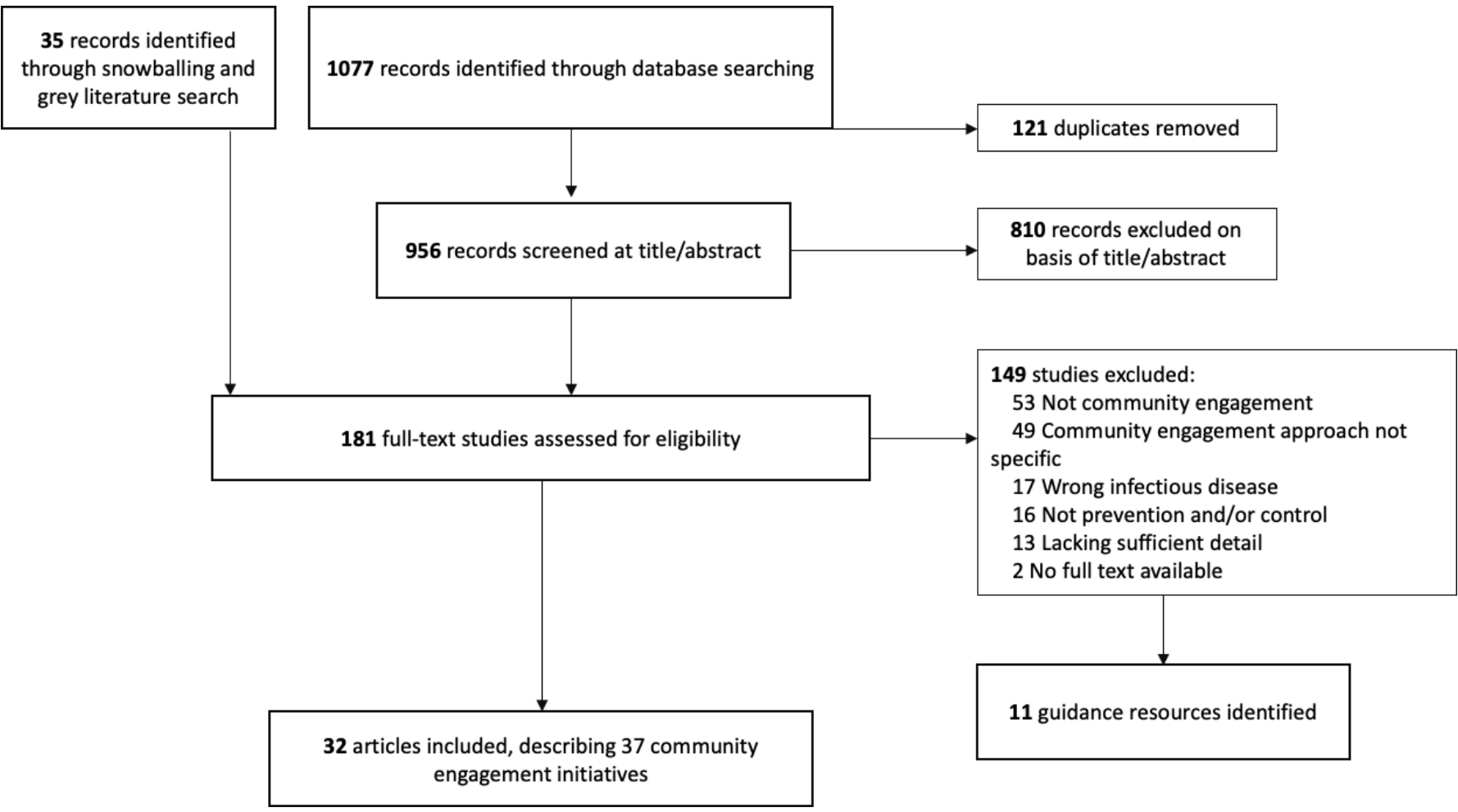

Figure 1 Preferred Reporting Items for Systematic Reviews and Meta-Analyses diagram.

\section{RESULTS}

Database and snowballing searches occurred between 27 April and 2 May 2020. A total of 1112 articles were returned, and after duplicate removal, 956 abstracts were reviewed. In total, 32 articles were identified for inclusion, 5 of which were identified through snowballing (4 from initial grey literature/snowball search and 1 from reviewing included articles' references) and the remainder through database searches. Figure 1 presents the screening process and results.

In addition to the 32 documents included and reported within, 11 documents that did not address or describe a specific community engagement initiative but did provide overarching guidance to community engagement or aspects of community engagement were identified. These documents were retained to support our interpretation and implementation considerations for community engagement. Online supplemental file 3 includes these details.

\section{Article characteristics}

Of the 32 included articles, all but 3 were published on or after 2015, with 1 article published in $2009,{ }^{35} 1$ in $2010^{36}$ and 1 in $2012 .^{37}$ The remaining were published in $2015(\mathrm{n}=2), 2016(\mathrm{n}=6), 2017(\mathrm{n}=9), 2018 \quad(\mathrm{n}=3)$, $2019(\mathrm{n}=3)$ and $2020(\mathrm{n}=6)$. All articles were in English except for one, which was in French. ${ }^{38}$ Thirty-two articles were included, but two articles report three ${ }^{39}$ and four ${ }^{40}$ distinct community engagement initiatives. As such, the remainder of the review will focus on 37 initiatives.

\section{Context and outbreak}

Of these 37 initiatives, 28 were for Ebola, with 25 relating to the 2014-2015 West Africa outbreak from Sierra Leone $(n=11)$, Liberia $(n=9)$, Guinea $(n=2)$, Nigeria $(n=1)$, Ghana $(n=1)$ and one mixed-country study. The remaining three Ebola examples ${ }^{41-43}$ were related to the 2018-2020 outbreak in the Democratic Republic of Congo, two of which focused on efforts in Uganda. Five community engagement initiatives were used for Zika within the USA and Puerto Rico $(n=3)$, and one each in Singapore and Uruguay. ${ }^{44-47}$ Four articles were specific to $\mathrm{H} 1 \mathrm{~N} 1$, with three from Australia and one from Canada. ${ }^{35-3748}$ No articles were found that detailed community engagement for SARS or MERS. Figure 2 highlights the examples found per country and topic.

Broad contextual concerns preceding the outbreak refer to poverty, unemployment or economic crisis, ${ }^{38}{ }^{49}$ health system failure, lack of development infrastructure, ${ }^{49}{ }^{50}$ colonial/postcolonial factors, ethnic and political conflicts, ${ }^{38} 39$ lack of trust in government and international agencies, ${ }^{42}$ traditional practices and rituals that are resistant to change, ${ }^{1551}$ geographical challenges $^{52}$ and mobile populations. ${ }^{53}$

\section{Community engagement approaches and interventions}

The review identified six broad types of community engagement actors or approaches, which addressed infection prevention and control through six main channels. As highlighted in table 2, the main actors included community leaders (traditional, religious and/ or governing); community and faith-based organisations 


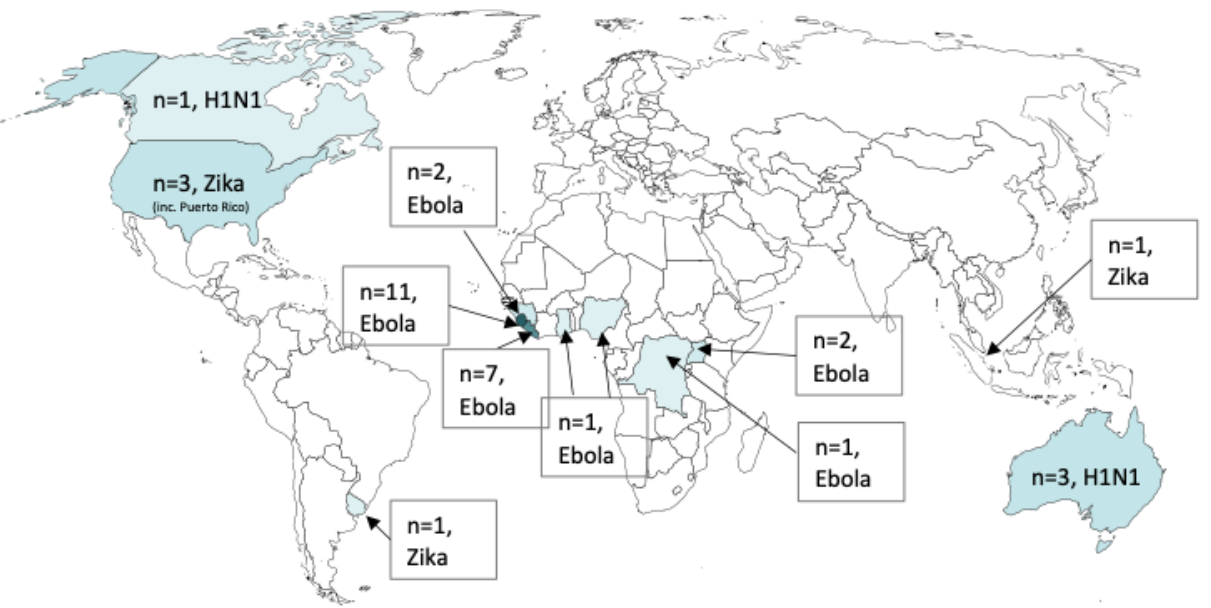

Figure 2 Number of articles per country and topic.

(CFBO); community groups or networks or committees; health management committees; individuals (no further clarification provided); and key stakeholders, which included students, survivors, women representatives, elderly and the youth. These community engagement interventions addressed infection prevention and control through six main channels: designing and planning interventions (including messaging), community entry and trust building, social and behavioural change communication (SBCC), risk communication, surveillance and contract tracing, and broader logistics and administration activities, such as procuring and setting up hand washing stations, constructing facility or record keeping.

From table 2, it can be seen that community engagement was mostly used for social and behavioural change communication and risk communication, followed by surveillance and contract tracing. Many of the reported community engagement activities involved multiple actors and took multifaceted approaches for prevention and control, as can be observed from table 2. For example, Skrip et al detail the Community-Led Ebola Action efforts implemented by the SMAC, which involved local radio stations to provide a platform for engagement with trusted community leaders, survivors and responders; community champions and mobilisers recruited from an existing cohort of CHWs, youth volunteers and people nominated by their communities; and religious leaders to promote key messages and role model behaviours to support community surveillance through standardised monitoring forms and a structured participatory dialogue to identify and address community needs targeting areas of trust building, risk communication and $\mathrm{SBCC}^{54}$; McMahon et al detail health management committees, made up of leaders and key stakeholders, and their efforts in SBCC and risk communication, and also supporting health facilities by conducting screening and administrative duties in relation to Ebola ${ }^{55}$; Ho and colleagues highlight how resident committees, grassroot leaders and volunteers conducted risk communication and source reduction for Zika ${ }^{45}$; and Mbaye and colleagues highlight how community groups, faith organisations and key stakeholders (youth, women and elderly) conducted trust building, surveillance and SBCC. ${ }^{38}$

The majority of the community engagement activities were not reported as a component of a larger programme, with the exception of surveillance systems which included community engagement for monitoring at the community level linked to a structured contract tracing system. Online supplemental file 2 includes the extraction data for each article.

\section{Target groups and equity considerations}

The majority of community engagement activities had community-wide focus, with no specific equity considerations reported. One article from Kirk Sell et at ${ }^{47}$ discusses CFBOs targeting marginalised populations, including non-English speakers and undocumented persons, in the USA for risk communication in relation to Zika. On the contrary, all articles in relation to H1N1 had an equity focus; remote and isolated First Nations communities in Canada ${ }^{37}$ and Aboriginal or Torres Strait Islanders communities in Australia. ${ }^{35} 36$ Important to note, however, is that community engagement for these communities was limited to design and planning, with no reported inclusion in implementation of activities.

Specific make-up of community engagement approaches was often not detailed or did not include diversity and representation, though several reported community engagement structures, including representation from Ebola survivors ${ }^{56}$ women within reproductive age and students, ${ }^{46}$ women representatives ${ }^{39}$ and youth. $^{3854} 56$

\section{Health system linkages and support}

Of those that provided details on linkages, very few were explicitly linked to other health system components (with the exception of tracing). Community health committees $^{53}$ and health management committees that were supporting health facility activities ${ }^{55}$ were linked 
Table 2 Community engagement actors and their involvement in epidemic prevention and control activities

\begin{tabular}{|c|c|c|c|c|c|c|}
\hline $\begin{array}{l}\text { Community engagement } \\
\text { actors }\end{array}$ & $\begin{array}{l}\text { Design and } \\
\text { planning }\end{array}$ & $\begin{array}{l}\text { Community entry/ } \\
\text { trust building }\end{array}$ & $\begin{array}{l}\text { Social and } \\
\text { behavioural change } \\
\text { communication }\end{array}$ & $\begin{array}{l}\text { Risk } \\
\text { communication }\end{array}$ & $\begin{array}{l}\text { Surveillance, } \\
\text { tracing }\end{array}$ & $\begin{array}{l}\text { Logistics, } \\
\text { provision, } \\
\text { administration }\end{array}$ \\
\hline \multirow[t]{2}{*}{$\begin{array}{l}\text { Leaders (traditional, } \\
\text { religious and governing) }\end{array}$} & $\begin{array}{l}\text { Charania and } \\
\text { Tsuji } 2012 \text {; } \\
\text { Juarbe-Rey et al }{ }^{46} \\
2018 \text {; } \\
\text { Miller et al }{ }^{48} 2015 \text {; } \\
\text { Kinsman et al } \\
2017^{78}\end{array}$ & 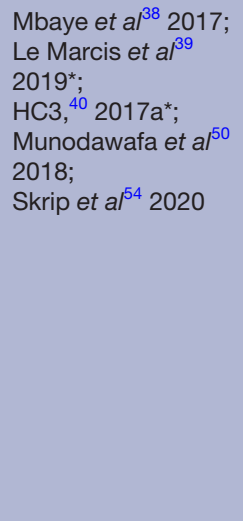 & 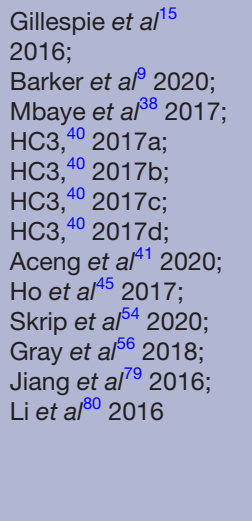 & 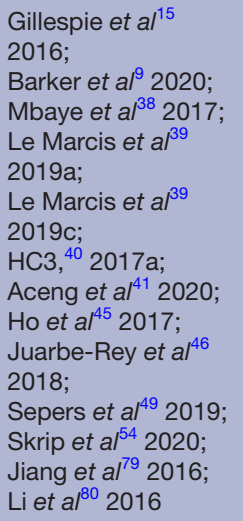 & 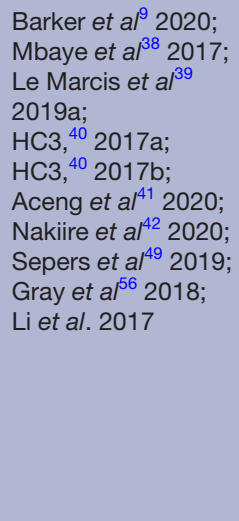 & $\begin{array}{l}\text { Barket et } a l^{9} 2020 ; \\
\text { Gray et } a l^{56} 2018 ; \\
\text { Le Marcis et } a l^{39} \\
\text { 2019c }\end{array}$ \\
\hline & $\begin{array}{l}\text { H1N1 }(n=2), \text { Zika } \\
(n=1), \text { Ebola }(n=1)\end{array}$ & Ebola $(n=5)$ & $\begin{array}{l}\text { Ebola }(n=12), \text { Zika } \\
(n=1)\end{array}$ & $\begin{array}{l}\text { Ebola }(n=12), \text { Zika } \\
(n=2)\end{array}$ & Ebola $(n=10)$ & Ebola $(n=3)$ \\
\hline \multirow[t]{2}{*}{$\begin{array}{l}\text { Community-based } \\
\text { organisations and faith } \\
\text { organisations }\end{array}$} & & Mbaye et al ${ }^{38} 2017$ & $\begin{array}{l}\text { Mbaye et } a l^{38} 2017 \\
\text { Santibañez et } a l^{51} \\
2017\end{array}$ & $\begin{array}{l}\text { Mbaye et } a l^{38} 2017 ; \\
\text { Kirk-Sell et al. } 2020 ; \\
\text { Adongo et } a l^{81} 2016\end{array}$ & Mbaye et al 2017 & $\begin{array}{l}\text { Santibañez et } a l^{51} \\
2017\end{array}$ \\
\hline & & Ebola $(n=1)$ & $\begin{array}{l}\text { Ebola }(n=1), \text { Zika } \\
(n=1)\end{array}$ & $\begin{array}{l}\text { Ebola }(n=2), \text { Zika } \\
(n=1)\end{array}$ & Ebola $(n=1)$ & Zika $(\mathrm{n}=1)$ \\
\hline \multirow[t]{2}{*}{ Community groups } & & Skrip et $a l^{54} 2020$ & 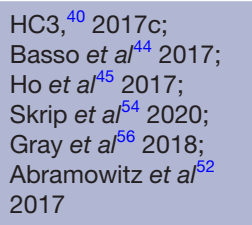 & $\begin{array}{l}\text { Le Marcis et } a l^{39} \\
2019 a ; \\
\text { Ho et } a l^{45} 2017 ; \\
\text { Skrip et } a l^{54} 2020\end{array}$ & $\begin{array}{l}\text { Le Marcis et } a l^{39} \\
2019 ; \\
\text { Gray et } a l^{56} 2018\end{array}$ & Gray et al ${ }^{56} 2018$ \\
\hline & & Ebola $(n=1)$ & $\begin{array}{l}\text { Ebola }(n=4), \text { Zika } \\
(n=2)\end{array}$ & $\begin{array}{l}\text { Ebola }(n=2), \text { Zika } \\
(n=1)\end{array}$ & Ebola $(n=2)$ & Ebola $(n=1)$ \\
\hline \multirow[t]{2}{*}{$\begin{array}{l}\text { Health management } \\
\text { committees/community } \\
\text { health committees }\end{array}$} & & & $\begin{array}{l}\text { McMahon et al }{ }^{55} \\
2017 ; \\
\text { Meredith, }{ }^{53} 2015\end{array}$ & $\begin{array}{l}\text { McMahon et } a l^{55} \\
2017 ; \\
\text { Meredith, }{ }^{53} 2015\end{array}$ & $\begin{array}{l}\text { McMahon et a }{ }^{55} \\
2017 ; \\
\text { Meredith, }{ }^{53} 2015\end{array}$ & $\begin{array}{l}\text { McMahon et }\left.a\right|^{55} \\
\text { 2017; } \\
\text { Meredith, }{ }^{53} 2015\end{array}$ \\
\hline & & & Ebola $(n=2)$ & Ebola $(n=2)$ & Ebola $(n=2)$ & Ebola $(n=2)$ \\
\hline \multirow[t]{2}{*}{ Individuals (volunteers) } & $\mathrm{HC} 3,{ }^{40} 2017 \mathrm{c}$ & Dada et $a l^{76} 2019$ & $\begin{array}{l}\text { Barker et } a l^{9} 2020 ; \\
\text { Aceng et } a l^{41} 2020 ; \\
\text { Skrip et } a l^{54} 2020 ; \\
\text { Jiang et } a l^{79} 2016 ; \\
\text { Maduka et } a l^{82} 2017\end{array}$ & $\begin{array}{l}\text { Barker et } a l^{9} 2020 ; \\
\text { Aceng et } a l^{41} 2020 \\
\text { Skrip et } a l^{54} 2020 \\
\text { Jiang et } a l^{79} 2016\end{array}$ & $\begin{array}{l}\text { Barker et al }{ }^{9} 2020 ; \\
\text { Aceng et } a l^{41} 2020 ; \\
\text { Nakiire et al }{ }^{42} 2020 ; \\
\text { Ratnayake et al } \\
2016 ; \\
\text { Stone et al. } 2016^{84}\end{array}$ & Barker et al 2020 \\
\hline & Ebola $(n=1)$ & Ebola $(n=1)$ & Ebola $(n=5)$ & Ebola $(n=4)$ & Ebola $(n=5)$ & Ebola $(n=1)$ \\
\hline \multirow[t]{2}{*}{ Key stakeholders } & 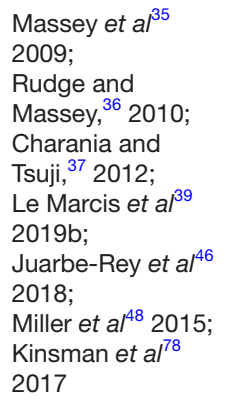 & Massey et $a /^{35} 2009$ & $\begin{array}{l}\text { Masumbuko et } a l^{43} \\
2020 ; \\
\text { Ho et } a l^{45} 2017 ; \\
\text { Gray et } a l^{56} 2018\end{array}$ & $\begin{array}{l}\text { Masumbuko et } a l^{43} \\
2020 ; \\
\text { Ho et al } \\
\text { Juarbe-Rey et } 2017 \\
2018 ; \\
\text { Li et } a l^{40} 2016\end{array}$ & Li et $a /^{80} 2016$ & \\
\hline & $\begin{array}{l}\text { H1N1 }(n=4), \text { Zika } \\
(n=1), \text { Ebola }(n=2)\end{array}$ & $\mathrm{H} 1 \mathrm{~N} 1(\mathrm{n}=1)$ & $\begin{array}{l}\text { Ebola }(n=3) \text {, Zika } \\
(n=1)\end{array}$ & $\begin{array}{l}\text { Ebola }(n=2), \text { Zika } \\
(n=2)\end{array}$ & Ebola $(n=1)$ & \\
\hline Totals & 12 & 9 & 32 & 29 & 20 & 8 \\
\hline
\end{tabular}

${ }^{*} \mathrm{HC} 3$ and Le Marcis have four and three examples of community engagement, respectively. For the purpose of this table, to demonstrate frequency of approaches, each example is cited as either a,b,c or d. However, as these come from the same included article, references do not appear this way within the reference list. 


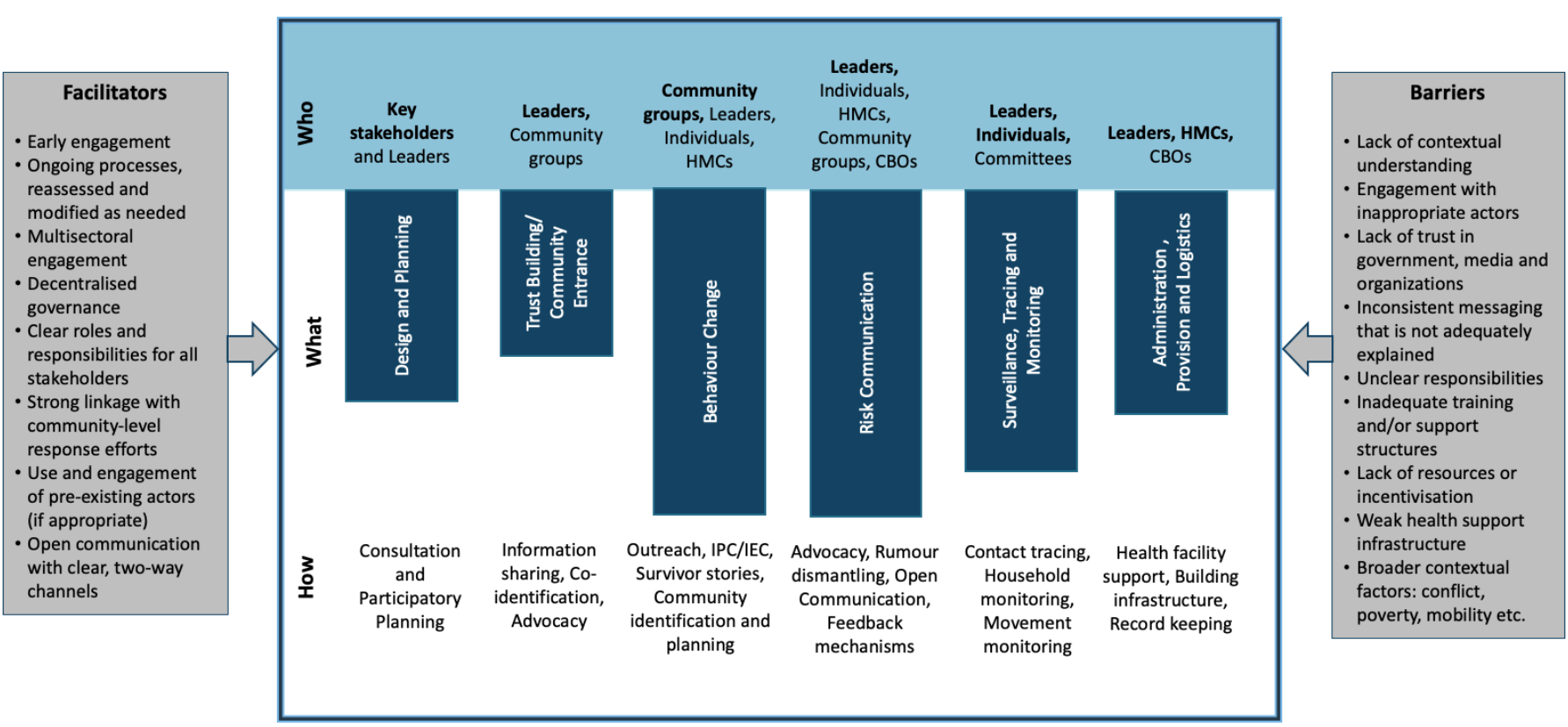

Figure 3 Components and implementation considerations of community engagement for infectious disease prevention and control. The main CE actors (who) most common for that specific process are in bold. The length of the bars varies based on the most common way (what) of community engagement as per the reviewed literature. 'How' represents key activities that were undertaken within each broader intervention classification. HMCs include community health committees. CFBO, community and faith-based organisation; HMC, health management committees; IEC, information, education and communication; IPC, interpersonal communication.

to community care centres, and Ebola survivors, leaders and youth groups were used for behavioural change and surveillance, and linked with existing CHWs. ${ }^{56}$

\section{Best practices for community engagement during epidemic response}

Key barriers and facilitators for community engagement for COVID-19 prevention and control that were extracted from the included studies are presented in figure 3. More broad implementation considerations synthesised from guidance documents are provided in online supplemental file 3, which emphasise the need for community engagement, which has to be context specific as per the cultures, traditions and customs, social norms and collective beliefs. Understanding local realities may require social research, including anthropological studies, if possible, and research to uncover knowledge gaps and existing sociocultural barriers. Community engagement should be an ongoing, collaborative process that starts early with community members who are seen as legitimate actors able to represent and influence the community. Communities should be involved in issue identification and codesign of interventions and response. A two-way dialogue with communities and other stakeholders, essential for trust building, should be established through multiple channels with transparent, accurate and consistent information to help address rumours and misconceptions. Messages should be imparted which are focused, not fear inducing, respectful, tailored to local contexts, with relatable examples. Regular feedback mechanism for monitoring and course correction that reveal how knowledge, beliefs and practices are changing are also needed for inclusive and meaningful engagement. These considerations are also discussed in a policy brief on this research targeted towards implementers. ${ }^{57}$

Reviewing the aforementioned findings and materials, in addition to considering the unique attributes of the COVID-19 pandemic and important guidance put forth by WHO, UNICEF and IFRC on 'Community-based healthcare, including outreach and campaigns, in the context of the COVID-19 pandemic, ${ }^{58}$ had led to development of key programme and policy recommendations for using community engagement in prevention and control approaches. Box 1 summarises these considerations, which aim to guide best practice.

\section{DISCUSSION}

Engagement lies on a spectrum, from more passive to active involvement. It can consist of providing information and conducting consultation; having involvement via regular interactions throughout the project cycle; and collaboration, which entails working in partnership with shared decisionmaking $^{5960}$ that involves communities carrying out critical health systems functions and innovating with localised solutions. ${ }^{9}$ Within this review, most included articles could be classified as having involvement, where communities were thoroughly brought in but often did not share decision-making powers. Notably, however, almost all examples of community engagement from high-income contexts consisted of consultation, demonstrating passive involvement with target ethnic and minority population. In addition, very few examples were identified that had an equity focus or strong equity considerations within target groups and engagement actors. 
Box 1 Key programme and policy recommendations

for COVID-19 prevention and control though community

engagement approaches

- Early discussions and negotiation with communities to understand sociocultural contexts and developing culturally appropriate prevention and control strategies, what types of engagement interventions are safe, feasible and acceptable, and what existing platforms and initiatives can be leveraged to support COVID-19 activities. Best practice, key actors and approaches for this have been outlined previously and in figure 3 .

- Communities should codesign and support delivery of prevention and control interventions and messaging (interpersonal communication/information, education and communication), including the development of appropriate, evidence-based messaging. Best practice, key actors and approaches for this have been outlined earlier and in figure 3.

- COVID-19 pandemic management teams incorporate community members into planning, response and monitoring of standard operating procedures. These plans should be disseminated within communities to ensure support. This should include topics of

- Population movement monitoring, surveillance and contact tracing systems discussed.

- Community remote monitoring and alert systems.

- Community response mechanisms if cases occur, including social isolation procedures, enacting contract tracing, quarantine procedures and community quarantine options.

- Lockdown, isolation or quarantine support, especially for vulnerable populations, including distribution of essential supplies.

- Referral pathways and medical supply procurement for serious cases.

- Planning and community sensitisation on safe burials.

- Health and safety considerations should be collaboratively identified and addressed in planning stages. These include the safe structuring of engagement activities, such as delivery mode of engagement; appropriate distancing measures for face-to-face interactions; quarantine or isolation procedures of community; availability of water and sanitation supplies; resource procurement for engagement actors, such as personal protective equipment; and protocols for suspected/confirmed contact with COVID-19-positive persons.

While leadership buy-in is imperative for many community activities, so too is ensuring a balance between power and representation of diverse voices.

Findings from this review highlight a need for more documentation of community engagement activities especially from more diverse geographical settings and across different populations. While some activities are under way, for instance, GOAL Global, based on experience gained from their Ebola response, is implementing community-led action for COVID-19 in numerous countries ${ }^{61}$ or community action networks in Cape Town working together to identify and address the needs of community members, ${ }^{62}$ implementers, policy makers and researchers, and encouraged to share learnings from past community engagement initiatives and document ongoing activities for COVID-19.

Interpretation of these findings should be done based on existing context, as the majority of articles were from Ebola response. Ebola had many unique considerations, including lack of trust, fear, rumours and cultural practices around burials and stigma. ${ }^{15}$ Engagement of local leaders, those with high levels of respect, were critical to support dismantling some of these notions and working towards prevention and control activities. However, the COVID-19 response may parallel Ebola in many ways, given the social spreading and potential stigma around contracting COVID-19. Additionally, most examples were implemented in low-income countries or in high-income countries where community engagement was used to target minority populations for $\mathrm{H} 1 \mathrm{~N} 1$ and Zika. There is a need for more documentation on community engagement from more diverse geographical settings and with different populations. Implementers, policy makers and researchers are encouraged to share learnings from past engagement initiatives and to document ongoing engagement for COVID-19 activities.

Countries with pre-existing community engagement structures with strong ties between health teams and communities can thoroughly and meaningfully embed such actions into national response plans. Recent modelling in Africa, where the large majority of articles including this review are based, has noted that, if not controlled, COVID-19 could result in up to 190000 deaths and 44million infections in 1year alone. ${ }^{63}$ Many South Asian countries, which have recently seen exponential increases in COVID-19 cases, have a long history of community health and engagement activities and were some of the first to document the mobilisation of CHWs like India's accredited social health activists (ASHAs), for COVID-19. Countries without a strong history of community engagement need to identify where this may be most beneficial, for instance, to support ethnic minorities in the global North who in many countries, because of inequitable systems, are being infected and killed at a disproportionate rate. $^{64}$

Community engagement may be specifically appropriate and needed for complex contexts, such as for migrants in humanitarian settings ${ }^{65}$ or in urban informal settlements. ${ }^{66}$ It is also needed to address more complex situations, such as settings dealing with both COVID-19 and risk of hunger ${ }^{67}$ or supporting already overburdened health systems.

Worthy of note are the limitations of community engagement within the COVID-19 context due to restrictions related to large gatherings and traditional faceto-face approaches. Innovative approaches to adapt traditional community engagement approaches may be required, and how governments and organisations overcome these barriers should be well documented, evaluated and shared. If done physically, COVID-19 prevention and control guidelines around physical distancing, wearing of masks and practising good respiratory and hand hygiene should be ensured. Alternatively, new innovations within community engagement may be more suitable, which may relate to technology and digital tools. Emerging examples of community engagement via digital methods in the COVID-19 context have included the involvement of community governance systems and CHWs in garnering acceptance for quarantine measures in China, ${ }^{68}$ mobilising local resources and volunteers 
and using social media tools such as WhatsApp to collect health information and communicating COVID-19 messages in Syria, ${ }^{69}$ and working with community local and religious leaders to deliberate on facilitators and barriers in the USA and to disseminate COVID-19 information using conference calls. ${ }^{70}$

Key lessons identified (box 1) in additional to early insights from COVID-19 also highlight the need to seriously consider how and what, information is being presented to all stakeholders and especially communities. An overabundance of information, accurate or not, also called 'infodemic', may have serious consequences for community stakeholders, not limited to lack of trustworthiness, confusion and resistance. Key to combatting infodemics and supporting proper communication will be identifying and dispelling rumours through the use of community leaders, open channels for two-way communication between organisations/government officials and community actors who have been prepared to identify misinformation and to support accurate messaging, and transparent and honest messaging with communities that also addresses and explains any changes to information.

Of further importance is that community engagement does not occur in a vacuum. It should be part of wider systems approaches and initiatives to address COVID-19. Ensuring appropriate health systems supports and buy-in will be fundamental to its success. Additionally, contextual community and implementation factors can largely influence the success of community engagement, ${ }^{71}$ with approaches being considered within the wider system of implementation. This may involve improving community capacity ${ }^{72}$ and supportive environments for engagement, supporting linkages and supportive policy and funding environments ${ }^{73} 74$ and establishing environments of respect, trust and shared values and goals. ${ }^{73}$ Using existing frameworks or standards for community engagement, such as UNICEF's 16 Minimum Standards for Community Engagement ${ }^{75}$ to support planning, implementation and monitoring, is encouraged to support highquality implementation.

Community engagement supports shaping social dynamics based on power and control that perpetuate the marginalisation of certain groups. The actors involved in mobilisation efforts and decision-making need to be seen as legitimate by the other members of the community. Recognising that power and legitimacy are contested resources that may be changed over the course of the outbreak is crucial for effective community engagement. ${ }^{39}$ It needs to start early and continue after the critical stages of the health crisis to contribute to empowerment and building resilient communities. Addressing COVID-19 will require multisectoral responses and a variety of approaches from biomedical and social sciences. Community engagement should be a fundamental component within all of these responses. Whether it be related to prevention and control, vaccine testing and ethics $^{76}$ or resilience and recovery, ${ }^{9}$ community engagement can support successful efforts. It can also have fundamental roles in rebuilding a stronger health system after the more acute phase of COVID-19 and supporting an equity-focused public health response. However, for all of these to work, community engagement needs to be meaningful, to follow best practice recommendations and guidelines, and to be specific to the context.

\section{Limitations}

As this was a rapid review, our database searching and snowballing were limited in scope and time, which may have resulted in missing articles. In addition, while our search terms attempted to include all relevant topics related to community engagement, and we did include search terms for specific community-based interventions (ie, SBCC and risk communication), this was not exhaustive, which may have resulted in missing articles. Excluding articles with a predominantly CHW focus may have resulted in missing some interventions that detail CHWs and other community engagement actors, though this review did attempt to include such studies. Several articles were limited in detail, and extracting and labelling content were at the review team's discretion, which may have resulted in incorrect coding on the type of actors and interventions. This may have been particularly relevant in situations where the engagement approaches and interventions conducted were of similar nature, for instance, the distinction between CFBOs and community groups, and SBCC and risk communication. Nevertheless, this review shares important lessons regarding community engagement approaches from past epidemics that should guide COVID-19 response.

\section{CONCLUSION}

COVID-19's global presence and social transmission pathways require social and community responses. This may be particularly important to reach marginalised populations and support equity-informed responses. Previous experience from outbreaks shows that community engagement can take many forms and include different actors and approaches who support various prevention and control activities, including design and planning, community entry and trust building, social and behaviour change communication, risk communication, surveillance and tracing, and logistics and administration. Countries worldwide are encouraged to assess existing community engagement structures and to use community engagement approaches to support contextually specific, acceptable and appropriate COVID-19 prevention and control measures.

\section{Author affiliations}

${ }^{1}$ UCD Centre for Interdisciplinary Research, Education and Innovation in Health Systems (UCD IRIS), School of Nursing, Midwifery and Health Systems, University College Dublin, Dublin, Ireland

${ }^{2}$ Department of Disease Control and Environmental Health, School of Public Health, College of Health Sciences, Makerere University, Kampala, Uganda

${ }^{3}$ Expanded Programme on Immunization, Ministry of Health, Yaoundé, Cameroon ${ }^{4}$ RTI International, Pasig City, Philippines

${ }^{5} \mathrm{Heller}$ School for Social Policy and Management, Brandeis University, Waltham, Massachusetts, USA

${ }^{6}$ République de Guinée Ministère de Santé, Conakry, Guinea

${ }^{7}$ United Nations University International Institute for Global Health, Kuala Lumpur,

Kuala Lumpur, Malaysia

${ }^{8}$ Public Health Foundation of India, Haryana, India 
${ }^{9}$ Community Health-Community of Practice Collectivity, United Nations Children's Fund (UNICEF) Headquarters, New York City, New York, USA

Twitter Brynne Gilmore @brynne.gilmore and Claudia Lopes @cabreulopes

Acknowledgements We thank Community Health-Community of Practice members and other networks who shared reports, guidelines and tools; Professor Bruno Meessen and Hannah Sarah F Dini for providing inputs into the protocol development; and Jiawen Elyssa Liu for supporting dissemination.

Contributors BG, SB and CL proposed and designed the study. All authors contributed to searching, screening, extraction and synthesis of articles. EM, RN and BG prepared the first draft of the manuscript, with all authors reviewing and providing inputs. All authors prepared and approved the final version of the manuscript. This research is a co-production of the Community Health-Community of Practice of which all authors are members.

Competing interests None declared.

Patient and public involvement Patients and/or the public were not involved in the design, conduct, reporting or dissemination plans of this research.

\section{Patient consent for publication Not required.}

Provenance and peer review Not commissioned; externally peer reviewed.

Data availability statement All data relevant to the study are included in the article or uploaded as supplementary information. All relevant data are included as supplementary files.

Open access This is an open access article distributed in accordance with the Creative Commons Attribution Non Commercial (CC BY-NC 4.0) license, which permits others to distribute, remix, adapt, build upon this work non-commercially, and license their derivative works on different terms, provided the original work is properly cited, appropriate credit is given, any changes made indicated, and the use is non-commercial. See: http://creativecommons.org/licenses/by-nc/4.0/.

ORCID iD

Brynne Gilmore http://orcid.org/0000-0003-4496-9254

\section{REFERENCES}

1 Rifkin SB. Lessons from community participation in health programmes: a review of the post Alma-Ata experience. Int Health 2009;1:31-6.

2 Rifkin SB. Examining the links between community participation and health outcomes: a review of the literature. Health Policy Plan 2014;29:ii98-106.

3 Odugleh-Kolev A, Parrish-Sprowl J. Universal health coverage and community engagement. Bull World Health Organ 2018;96:660-1.

4 Baltzell K, Harvard K, Hanley M, et al. What is community engagement and how can it drive malaria elimination? case studies and stakeholder interviews. Malar J 2019;18:245.

5 Gilmore B, McAuliffe E, Larkan F, et al. How do community health committees contribute to capacity building for maternal and child health? A realist evaluation protocol. BMJ Open 2016;6:e011885.

6 Gilmore $B$, Vallières $F$, McAuliffe $E$, et al. The last one heard: the importance of an early-stage participatory evaluation for programme implementation. Implement Sci 2014;9:137.

7 Bath J, Wakerman J. Impact of community participation in primary health care: what is the evidence? Aust J Prim Health 2015;21:2-8.

8 Sacks E, Swanson RC, Schensul JJ, et al. Community involvement in health systems strengthening to improve global health outcomes: a review of guidelines and potential roles. Int Q Community Health Educ 2017;37:139-49.

9 Barker KM, Ling EJ, Fallah M, et al. Community engagement for health system resilience: evidence from Liberia's Ebola epidemic. Health Policy Plan 2020;35:416-23.

10 Questa K, Das M, King R, et al. Community engagement interventions for communicable disease control in low- and lowermiddle-income countries: evidence from a review of systematic reviews. Int J Equity Health 2020;19:1-20.

11 Storey JD, Chitnis K, Obregon R, et al. Community engagement and the communication response to Ebola. J Health Commun 2017;22:2-4

12 Laverack G, Manoncourt E. Key experiences of community engagement and social mobilization in the Ebola response. Glob Health Promot 2016;23:79-82.

13 Kuruvilla S, Bustreo F, Kuo T, et al. The global strategy for women's, children's and adolescents' health (2016-2030): a roadmap based on evidence and country experience. Bull World Health Organ 2016:94:398-400.

14 Kickbusch I, Reddy KS. Community matters - why outbreak responses need to integrate health promotion. Glob Health Promot 2016;23:75-8.

15 Gillespie AM, Obregon R, El Asawi R, et al. Social mobilization and community engagement central to the Ebola response in West Africa: lessons for future public health emergencies. Glob Health $\mathrm{Sci}$ Pract 2016;4:626-46.

16 Menon KU, Goh KT. Transparency and trust: risk communications and the Singapore experience in managing SARS. JCOM 2005:9:375-83.

17 Toppenberg-Pejcic D, Noyes J, Allen T, et al. Emergency risk communication: lessons learned from a rapid review of recent gray literature on Ebola, Zika, and yellow fever. Health Commun 2019;34:437-55

18 Chan M. Ebola virus disease in West Africa--no early end to the outbreak. N Engl J Med 2014;371:1183-5.

19 Marais F, Minkler M, Gibson N, et al. A community-engaged infection prevention and control approach to Ebola. Health Promot Int 2016;31:440-9.

20 Singaravelu S, Shadid J, Anoko J, et al. Risk communication, community engagement and social mobilization during the outbreak of Ebola virus disease in Equateur Province, Democratic Republic of the Congo, in 2018. Wkly Epidemiol Rec 2019;94:32-6.

21 Vinck P, Pham PN, Bindu KK, et al. Institutional trust and misinformation in the response to the 2018-19 Ebola outbreak in North Kivu, DR Congo: a population-based survey. Lancet Infect Dis 2019;19:529-36

22 Carter SE, O'Reilly M, Frith-Powell J, et al. Treatment seeking and Ebola community care centers in Sierra Leone: a qualitative study. $J$ Health Commun 2017;22:66-71.

23 Bedson J, Jalloh MF, Pedi D, et al. Community engagement during outbreak response: Standards, approaches, and lessons from the 2014-2016 Ebola outbreak in Sierra Leone. bioRxiv 2019;661959.

24 Marston C, Renedo A, Miles S. Community participation is crucial in a pandemic. Lancet 2020;395:1676-8.

25 World Health Organization, International Federation of the Red Crescent, UNICEF. Risk communication and community engagement (RCCE) action plan guidance COVID-19 preparedness and response. Geneva, Switzerland: World Health Organization, 2020.

26 Sohrabi C, Alsafi Z, O'Neill N, O’Neill N, et al. World Health organization declares global emergency: a review of the 2019 novel coronavirus (COVID-19). Int J Surg 2020;76:71-6.

27 Rajan D, Koch K, Rohrer K, et al. Governance of the Covid-19 response: a call for more inclusive and transparent decision-making. BMJ Glob Health 2020;5:e002655.

28 Bavel JJV, Baicker K, Boggio PS, et al. Using social and behavioural science to support COVID-19 pandemic response. Nat Hum Behav 2020;4:460-471.

29 Van den Broucke S. Why health promotion matters to the COVID-19 pandemic, and vice versa. Health Promot Int 2020;35:181-6.

30 Laverack G. Communities and COVID-19: perspectives from a health promotion expert, 2020

31 Bhaumik S, Moola S, Tyagi J, et al. Frontline health workers in COVID-19 prevention and control: rapid evidence synthesis. India: George Institute for Global Health, 2020.

32 Langlois EV, Straus SE, Antony J, et al. Using rapid reviews to strengthen health policy and systems and progress towards universal health coverage. BMJ Glob Health 2019;4:e001178.

33 Tricco AC, Langlois EV, Straus SE. Rapid reviews to strengthen health policy and systems: a practical guide. Geneva: World Health Organization, 2017.

34 Collectively T. Refining the community health conceptual framework, 2019.

35 Massey P, Pearce G, Taylor KA. Reducing the risk of pandemic influenza in Aboriginal communities, 2009.

36 Rudge S, Massey PD. Responding to pandemic (H1N1) 2009 influenza in Aboriginal communities in NSW through collaboration between NSW health and the Aboriginal community-controlled health sector. N S W Public Health Bull 2010;21:26-9.

37 Charania NA, Tsuji LJS. A community-based participatory approach and engagement process creates culturally appropriate and community informed pandemic plans after the $2009 \mathrm{H} 1 \mathrm{~N} 1$ influenza pandemic: remote and isolated first nations communities of subarctic Ontario, Canada. BMC Public Health 2012;12:268.

38 Mamadou Mbaye E, Kone S, Kâ O, et al. [Evolution of Community engagement in the fight against Ebola]. Sante Publique 2017;29:487-96.

39 Le Marcis F, Enria L, Abramowitz S. Three acts of resistance during the 2014-16 West Africa Ebola epidemic, 2019. 
40 Health Communication Capacity Collaborative (HC3). Social mobilization lessons learned: the Ebola response in Liberia. Baltimore, Maryland: Johns Hopkins Centre for Communication Programs, 2017

41 Aceng JR, Ario AR, Muruta AN, et al. Uganda's experience in Ebola virus disease outbreak preparedness, 2018-2019. Global Health 2020;16:24.

42 Nakiire L, Mwanja H, Pillai SK, et al. Population movement patterns among the democratic republic of the Congo, Rwanda, and Uganda during an outbreak of ebola virus disease: results from community engagement in two districts - Uganda, march 2019. MMWR Morb Mortal Wkly Rep 2020;69:10-13.

43 Masumbuko Claude K, Hawkes MT. Ebola crisis in eastern democratic republic of Congo: student-led community engagement. Pathog Glob Health 2020;114:218-23.

44 Basso C, García da Rosa E, Lairihoy R, et al. Scaling up of an innovative intervention to reduce risk of dengue, Chikungunya, and Zika transmission in Uruguay in the framework of an Intersectoral approach with and without community participation. Am J Trop Med Hyg 2017;97:1428-36.

45 Ho Z, Hapuarachchi HC, et al, The Singapore Zika Study Group. Outbreak of Zika virus infection in Singapore: an epidemiological, entomological, virological, and clinical analysis. Lancet Infect Dis $2017 ; 17: 813-21$

46 Juarbe-Rey D, Pérez AO, Santoni RPCP, et al. Using risk communication strategies for Zika virus prevention and control driven by community-based participatory research. Int $J$ Environ Res Public Health 2018;15:2505.

47 Kirk Sell T, Ravi SJ, Watson C, et al. A public health systems view of risk communication about Zika. Public Health Rep 2020;135:343-53.

48 Miller A, Massey PD, Judd J, et al. Using a participatory action research framework to listen to Aboriginal and Torres Strait Islander people in Australia about pandemic influenza. Rural Remote Health 2015;15:1-10.

49 Sepers CE, Fawcett SB, Hassaballa I, et al. Evaluating implementation of the Ebola response in Margibi County, Liberia. Health Promot Int 2019;34:510-8.

50 Munodawafa D, Moeti MR, Phori PM, et al. Monitoring and evaluating the Ebola response effort in two Liberian communities. $J$ Community Health 2018;43:321-7.

51 Santibañez S, Lynch J, Paye YP, et al. Engaging community and faith-based organizations in the Zika response, United States, 2016. Public Health Rep 2017;132:436-42.

52 Abramowitz S, McKune SL, Fallah M, et al. The opposite of denial: social learning at the onset of the Ebola emergency in Liberia. $J$ Health Commun 2017;22:59-65.

53 Meredith C. A bottom-up approach to the Ebola response. Humanitarian Exchange2015;64.

54 Skrip LA, Bedson J, Abramowitz S, et al. Unmet needs and behaviour during the Ebola response in Sierra Leone: a retrospective, mixed-methods analysis of community feedback from the social mobilization action Consortium. Lancet Planet Health 2020;4:e74-85.

55 McMahon SA, Ho LS, Scott K, et al. "We and the nurses are now working with one voice": How community leaders and health committee members describe their role in Sierra Leone's Ebola response. BMC Health Serv Res 2017;17:495.

56 Gray N, Stringer B, Bark G, et al. 'When Ebola enters a home, a family, a community': a qualitative study of population perspectives on Ebola control measures in rural and urban areas of Sierra Leone. PLoS Negl Trop Dis 2018;12:e0006461.

57 Bhattacharyya S, Abreu Lopes C, Nyamupachitu-Mago E, et al. Research Brief: Community Engagement for COVID-19 Infection Prevention and Control: A Rapid Review of the Evidence. In: A co-production of the community health - community of practice. UNICEF, 2020.

58 WHO, UNICEF. Community-based health care, including outreach and campaigns, in the context of the COVID-19 pandemic. Geneva: Interim guidance, 2020.

59 Spencer J, Gilmore B, Lodenstein E, et al. A mapping and synthesis of tools for stakeholder and community engagement in quality improvement initatives for reproductive, maternal, newborn, child and adolescent health. Forthcoming.

60 World Health Organization, UNICEF. Integrating stakeholder and community engagement in quality of care initiatives for maternal, newborn and child health. In: A module of the 'Improving the quality of care for maternal, newborn and child health - Implementation guide for facility, district and national levels. Geneva: Organization $\mathrm{WH}, 2020$.

61 McCrossan G, Owen K. CLA for COVID-19: resource guide. Dublin, Ireland: Global G, 2020.
62 van Ryneveld M, Whyle E, Brady L, et al. Cape town together: organizing in a city of islands. Network WCA, 2020.

63 Cabore JW, Karamagi HC, Kipruto H, et al. The potential effects of widespread community transmission of SARS-CoV-2 infection in the world Health organization African region: a predictive model. BMJ Glob Health 2020;5:e002647.

64 Yaya S, Yeboah $\mathrm{H}$, Charles $\mathrm{CH}$, et al. Ethnic and racial disparities in COVID-19-related deaths: counting the trees, hiding the forest. BMJ Glob Health 2020;5:e002913.

65 Hargreaves S, Zenner D, Wickramage K, et al. Targeting COVID-19 interventions towards migrants in humanitarian settings. Lancet Infect Dis 2020;20:645-6.

66 Van Belle S, Affun-Adegbulu C, Soors W, et al. COVID-19 and informal settlements: an urgent call to rethink urban governance. Int $J$ Equity Health 2020;19:1-2.

67 Rashid SF, Theobald S, Ozano K. Towards a socially just model: balancing hunger and response to the COVID-19 pandemic in Bangladesh. BMJ Glob Health 2020;5:e002715.

68 Zhu J, Cai Y. Engaging the communities in Wuhan, China during the COVID-19 outbreak. Glob Health Res Policy 2020;5:35.

69 Ekzayez A, Al-Khalil M, Jasiem M, et al. COVID-19 response in northwest Syria: innovation and community engagement in a complex conflict. J Public Health 2020.

70 Galiatsatos P, Monson K, Oluyinka M, et al. Community calls: lessons and insights gained from a Medical-Religious community engagement during the COVID-19 pandemic. J Relig Health 2020. doi:10.1007/s10943-020-01057-w. [Epub ahead of print: 27 Jun 2020].

71 Sarrami-Foroushani P, Travaglia J, Debono D, et al. Implementing strategies in consumer and community engagement in health care: results of a large-scale, scoping meta-review. BMC Health Serv Res 2014; 14:402.

72 Lavery JV, Tinadana PO, Scott TW, et al. Towards a framework for community engagement in global health research. Trends Parasitol 2010;26:279-83.

73 Howard-Grabman L, Miltenburg AS, Marston C, et al. Factors affecting effective community participation in maternal and newborn health programme planning, implementation and quality of care interventions. BMC Pregnancy Childbirth 2017; 17:268

74 Marston C, Hinton R, Kean S, et al. Community participation for transformative action on women's, children's and adolescents' health. Bull World Health Organ 2016;94:376-82.

75 UNICEF. Minimum quality standards and indicators in community engagement a guidance towards high quality, evidence-based community engagement in development and humanitarian contexts. New York: UNICEF, 2020.

76 Dada S, McKay G, Mateus A, et al. Lessons learned from engaging communities for Ebola vaccine trials in Sierra Leone: reciprocity, relatability, relationships and respect (the four R's). BMC Public Health 2019;19:1665.

77 George A, Scott K, Garimella S, et al. Anchoring contextual analysis in health policy and systems research: a narrative review of contextual factors influencing health committees in low and middle income countries. Soc Sci Med 2015;133:159-67.

78 Kinsman J, de Bruijne K, Jalloh AM, Harris M, et al. Development of a set of community-informed Ebola messages for Sierra Leone. PLoS Negl Trop Dis 2017;11:e0005742.

79 Jiang H, Shi G-Q, Tu W-X, et al. Rapid assessment of knowledge, attitudes, practices, and risk perception related to the prevention and control of Ebola virus disease in three communities of Sierra Leone. Infect Dis Poverty 2016;5:53.

80 Li Z-J, Tu W-X, Wang X-C, Shi G-Q, et al. A practical communitybased response strategy to interrupt Ebola transmission in Sierra Leone, 2014-2015. Infect Dis Poverty 2016;5:74.

81 Adongo PB, Tabong PT-N, Asampong E, et al. Preparing towards preventing and containing an Ebola virus disease outbreak: what Socio-cultural practices may affect containment efforts in Ghana? PLoS Negl Trop Dis 2016;10:e0004852.

82 Maduka O, Nzuki C, Ozoh HC, et al. House-to-house interpersonal communication in the containment of Ebola in Nigeria. J Commun Healthc 2017;10:31-6.

83 Ratnayake R, Crowe SJ, Jasperse J, et al. Assessment of community event-based surveillance for Ebola virus disease, Sierra Leone, 2015. Emerg Infect Dis 2016;22:1431-7.

84 Stone E, Miller L, Jasperse J, et al. Community event-based surveillance for Ebola virus disease in Sierra Leone: implementation of a nationallevel system during a crisis. PLoS Curr 2016;8. doi:10.1371/currents. outbreaks.d119c71125b5cce312b9700d744c56d8. [Epub ahead of print: 07 Dec 2016]. 